\title{
Roles and Mechanisms of Human Cathelicidin LL-37 in Cancer
}

\author{
Xi Chen ${ }^{a, b}$ Xianqiong Zou ${ }^{a}$ Guangying Q ${ }^{b, c}$ Ying Tang ${ }^{a} \quad$ Yong Guo Jia Sia,b \\ Lihua Liang $^{d}$ \\ ${ }^{a}$ College of Biotechnology, Guilin Medical University, Guilin, Guangxi, bCollege of Basic Medicine, \\ Guilin Medical University, Guilin, Guangxi, 'Laboratory of Tumor Immunology and Microenvironmental \\ Regulation, Guilin Medical University, Guilin, Guangxi, ${ }^{\mathrm{d} D e p a r t m e n t}$ of Stomatology, Affiliated Hospital \\ of Guilin Medical University, Guilin, Guangxi, P. R. China
}

\section{Key Words}

Cathelicidin • hCAP-18 • LL-37 • Tumorigenic effect • Anti-cancer

\begin{abstract}
LL-37, the C-terminal peptide of human cathelicidin antimicrobial peptide (CAMP, hCAP18), reportedly increases resistance to microbial invasion and exerts important physiological functions in chemotaxis, promotion of wound closure, and angiogenesis. Accumulating evidence indicates that LL-37 also plays a significant role in human cancer. LL-37 induces tumorigenic effects in cancers of the ovary, lung, breast, prostate, pancreas, as well as in malignant melanoma and skin squamous cell carcinoma. In contrast, LL-37 displays an anticancer effect in colon cancer, gastric cancer, hematologic malignancy and oral squamous cell carcinoma. Mechanistically, LL-37-induced activation of membrane receptors and subsequent signaling pathways lead to alteration of cellular functions. Different membrane receptors on various cancer cells appear to be responsible for the tissue-specific effects of LL-37. Meanwhile, the findings that vitamin D-dependent induction of cathelicidin in human macrophages activates the anti-cancer activity of tumor-associated macrophages (TAMs) and enhances antibody-dependent cellular cytotoxicity (ADCC) support critical roles of vitamin $D$-dependent induction of cathelicidin in cancer progression. This review describes novel advances involving the roles and mechanisms of human cathelicidin LL-37 in cancer.

(C) 2018 The Author(s)

Published by S. Karger AG, Basel
\end{abstract}

\section{Introduction}

Cathelicidins are antimicrobial peptides produced by mammals in response to various pathogenic microbes [1-5]. Human cathelicidin antimicrobial peptide (CAMP, hCAP-18) is the only member of the cathelicidin protein family in humans [1-5]. hCAP-18 (18kDa) is processed by proteolytic cleavage to bioactive cathelicidin LL-37 (37 amino acid residues with diLeucine at the $\mathrm{N}$-terminus) by exposure to specific serine proteases like proteinase 3, kallikrein 5 and kallikrein 7 [1]. hCAP-18 is widely expressed in various epithelial cells 


\section{Cellular Physiology Cell Physiol Biochem 2018;47:1060-1073 \begin{tabular}{c|c} 
DOI: 10.1159/000490183 & O 2018 The Author(s). Published by S. Karger AG, Basel \\
www.karger.com/cpb
\end{tabular}

and innate immune cells (neutrophils, monocytes, macrophages, dendritic cells, natural killer (NK) cells, lymphocytes and mast cells) [4]. The expression of hCAP-18 is constitutive in most epithelia although its expression in keratinocytes is induced by infection, vitamin D, butyrate, short-chain fatty acids and endoplasmic reticulum stress signaling [3-5]. hCAP-18 can be downregulated by pathogens such as Shigella and Neisseria, and some bacterial exotoxins [3-5].

It is well known that hCAP18/LL-37 has antimicrobial activities against bacteria, fungi, viruses, and parasites [5-9]. Low concentrations of LL-37 can prevent biofilm formation, and higher concentrations of LL-37 can destroy pre-existing biofilms [2, 10, 11]. Additional effects of human cathelicidin LL37 on cellular functions include activation of cell migration $[2,12]$, cell proliferation and

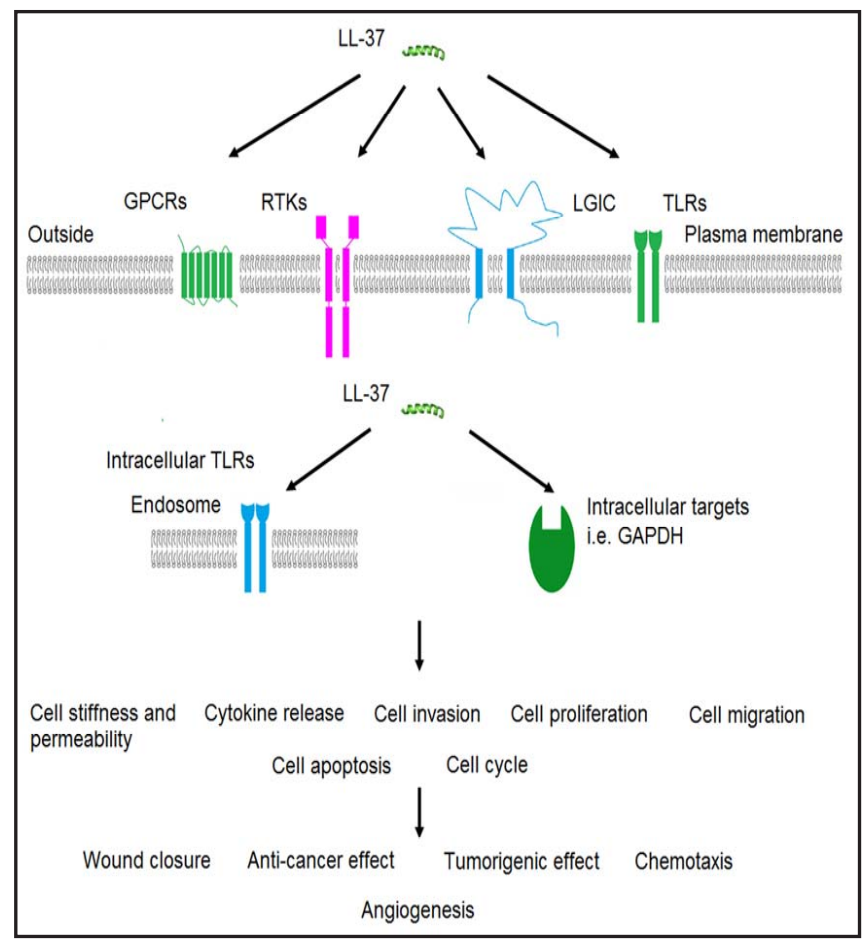

Fig. 1. Human cathelicidin LL-37 associated receptors and their cancer-related roles. GPCRs, G protein-coupled receptors. RTKs, receptor tyrosine kinases. LGIC, ligand-gated ion channel. TLRs, toll-like receptors. GAPDH, glyceraldehyde-3-phosphate dehydrogenase. invasion [2, 12-14], regulation of cell apoptosis (including inhibition and enhancement on different cells) $[2,15,16]$, cell cycle arrest $[2,15,16]$, modulation of cytokine release $[17,18]$, enhancement of stiffness and reduction of the transepithelial permeability of epithelial cells (Fig. 1) [19]. These LL37 induced alterations stimulate chemotaxis that directly attracts cells of innate immune system (e.g. monocytes, neutrophils, dendritic cells, mesenchymal stromal cells (MSCs)) [5, 20-22], while also promoting wound closure [2, 12] and angiogenesis (Fig. 1) $[2,23]$.

Emerging evidence supports cathelicidin LL-37 involvement in various types of human cancer [1-5, 24, 25]. Surprisingly, however, current data indicate that LL-37 can exert either pro-tumorigenic or anti-cancer effects $[1-5,24,25]$. To explain this conundrum, it has been proposed that the cell and tissue effects induced by LL-37 are mainly mediated via activation of specific cell surface receptors, membrane channels or intracellular targets that are differentially expressed in different cell types [26]. These LL-37-targeted receptors include at least four G protein-coupled receptors (GPCRs), three receptor tyrosine kinases (RTKs), a ligand-gated ion channel (LGIC) and toll-like receptors (TLRs) (Fig.1) [4, 26]. In particular, LL-37 targets include GPCRs such as N-formyl peptide receptor 2 (FPR2; formerly known as formyl peptide receptor like-1, FPRL1), CXC chemokine receptor type 2 (CXCR2), mas-related gene X2 (MrgX2) and purinergic receptor P2Y11 (P2Y11) [26]. Epidermal growth factor receptor (EGFR/ErbB1), insulin-like growth factor 1 receptor (IGF1R) and erb-b2 receptor tyrosine kinase 2 (ErbB2) are targeted RTKs by LL-37 [26], whereas LGIC is a targeted transmembrane channel purinergic receptor $7\left(\mathrm{P}^{2} \mathrm{X}_{7}\right)$ [26]. TLR-targets of LL-37 are type I transmembrane glycoproteins that are functionally important in the activation of innate immune cells [27]. Cell surface TLRs include TLR1, TLR2, TLR4, TLR5, TLR6 and TLR10, whereas endosomal TLRs include TLR3, TLR7, TLR8, and TLR9 [26-28]. LL-37 can also access other intracellular targets such as cytosolic protein glyceraldehyde-3-phosphate dehydrogenase (GAPDH) and consequently affects various intracellular biological processes [26, 29]. 


\section{Tumorigenic effects}

Compared to normal tissues, hCAP-18/LL-37 expression levels are upregulated in ovarian cancer, lung cancer, breast cancer, prostate cancer, pancreatic cancer, malignant melanoma (MM) and skin squamous cell carcinoma (SCC) [1, 2, 24, 30-33]. These observations suggest that LL-37 exerts a tumorigenic effect in these cancers [1, 2, 24, 30-34].

\section{Ovarian cancer}

LL-37 expression levels significantly increase in ovarian cancer tissues compared to the normal ovary tissues suggesting it might be a potential biomarker of ovarian cancer [2, 35]. In ovarian cancer cells, recombinant LL-37 induces cell proliferation, cell invasion, chemotaxis, and matrix metalloproteinase (MMP) expression [35]. The release and activation of MMPs mediate extracellular matrix (ECM) degradation that promotes cell invasion and metastasis of tumor cells [36, 37]. Mechanistically, LL-37 interaction with FPR2, a GPCR member, recruits MSCs into the tumor stroma, which enhances tumor progression [36, 38]. MSCs contribute to the carcinogenesis of ovarian cancer by enhancing the secretion of cytokine IL-1 $\beta$, IL-6, IL-8, IL-10 and TNF- $\alpha$, while diminishing IL-12 secretion (Fig. 2A) [36, 39]. MSCs are also responsible for the immunomodulation of various immune cell populations [36]. When MSCs are cultured with lung cancer cells, sphere formation and pluripotency markers including Nanog, Oct4A, and Sox2 are upregulated in lung cancer cells, suggesting a direct effect on the cancer stem cells (CSCs) population [40]. More recent findings confirm a direct link for hCAP18/LL-37 acting on pancreatic CSCs to negatively affect tumor growth [30].

Meanwhile, contrary effects of LL-37 on ovarian cancer cells have also been reported [41]. A combination of LL-37 with CpG-oligodeoxynucleotides (CpG-ODN), a TLR9 ligand, increases the CpG-ODN delivery into endosomes, which upregulates the expression of interferon $\gamma$ (INF $\gamma$ ), and then induces proliferation and activation of NK cells that can inhibit the cancer cells (Fig. 2A) [41].

A recent interesting report indicates that enhanced hCAP18/LL-37 expression in macrophages promotes ovarian cancer progression and that ovarian cancer cell-produced versican V1 enhances expression of hCAP-18/LL-37 in cultured macrophages [42]. The findings suggest that immune stromal cells (mainly monocytes and macropahges) are also an important source of LL-37 [42-45], and that cancer cells may manipulate the immune stromal cells into producing the LL-37 that they need.

\section{Lung cancer}

hCAP-18/LL-37 is expressed at elevated levels in human lung cancer cells at both the mRNA and protein levels $[2,42,46,47]$. Lung cancer cell lines that stably overexpress the hCAP-18 peptide also grow faster [46]. When these stably transfected cells were subcutaneously injected into nude mice, increased tumorigenicity and significantly larger tumor mass were observed [46]. Mechanistically, LL-37 induces EGFR phosphorylation and

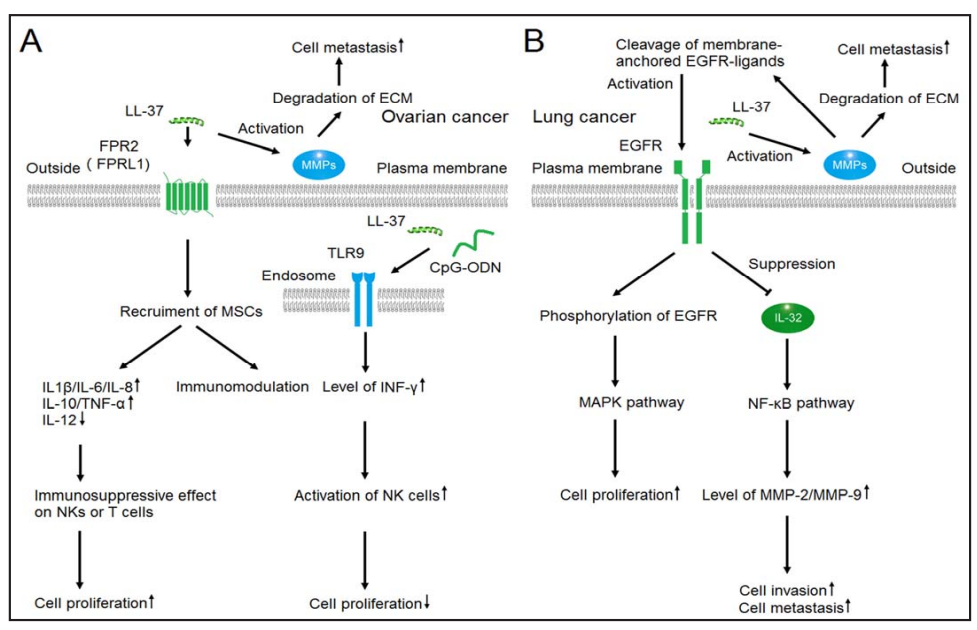

Fig. 2. Proposed tumorigenic mechanism of human cathelicidin LL-37 involvement in ovarian and lung cancer cells. (A) Ovarian cancer. (B) Lung cancer. FPR2, N-Formyl peptide receptor 2. FPRL-1, formly peptide receptor like-1. MSCs, mesenchymal stem cells. ECM, extracellular matrix. MMPs, matrix metalloproteinases. NK, natural killer. EGFR, epidermal growth factor receptor. MAPK, mitogen-activated protein kinases. IL, interleukin. INF, interferon. CpG-ODN, CpG oligodeoxynucleotides. 


\section{Cellular Physiology Cell Physiol Biochem 2018;47:1060-1073 \\ \begin{tabular}{c|c} 
DOI: 10.1159/000490183 & Ond Biochemistry \\
Published online: May 30, 2018 & $\begin{array}{l}\text { 2018 The Author(s). Published by S. Karger AG, Basel } \\
\text { www.karger.com/cpb }\end{array}$
\end{tabular} \\ Chen et al.: Mechanisms of LL-37 in Cancer}

activation of downstream mitogen-activated protein kinase (MAPK) signaling pathways, which increases cell proliferation and growth of anchorage-independent colonies in lung cancer cells (Fig. 2B) [46, 47]. LL-37 activates the EGFR through MMP-mediated cleavage of membrane-anchored EGFR-ligands (Fig. 2B) [2, 48]. On the other hand, IL-32 expression is distinctly altered in lung cancer cells and closely associated with increased lung cancer invasiveness, metastasis and poor prognosis $[48,49]$. Recent reports show that IL-32 also is involved in the invasion and metastasis of primary lung adenocarcinoma via NF- $\kappa B$ induced MMP-2 and MMP-9 expression [2, 49, 50]. Because LL-37 can significantly suppress IL-32induced production of pro-inflammatory cytokines and IL-32-mediated phosphorylation of Fyn (Y420) Src kinase [48], it was proposed that LL-37 can affect the carcinogenesis of lung cancer by suppressing the biological activity of IL-32 (Fig. 2B) [2, 51].

\section{Breast cancer}

The expression levels of hCAP-18/LL-37 in breast cancer tissues are higher than those of normal breast tissues [52]. In breast cancer cells the LL-37-targeted receptor, ErbB2, is amplified which helps induce cell migration, invasion and poor prognosis [53-55]. ErbB2 upregulation by LL-37 activates Heregulin (an ErbB3/ErbB4 ligand)-mediated MAPK signaling pathway in breast cancer cells, resulting not only in enhanced cell migration but also anchorage-independent growth (Fig. 3A) [56]. Overexpression of hCAP-18 in breast cancer cell line MJ1105 reportedly promotes the development of metastases in mice with severe combined immunodeficiency (SCID). The findings also revealed enhanced activation of MAPK signaling in hCAP-18 transgenic tumors [56]. It has been shown that LL-37 induces migration of breast cancer cell lines (MCF7, MDA-MB-435s and MDA-MB-231) by activating the transient receptor potential cation (TRPV2) and recruiting it to pseudopodia through activation of the PI3K/Akt pathway [54]. During this activation process, $\mathrm{Ca}^{2+}$ entry via the TRPV2 occurred in concert with $\mathrm{K}^{+}$efflux through the $\mathrm{Ca}^{2+}$-activated $\mathrm{K}^{+}$-channels $\left(\mathrm{BK}_{\mathrm{Ca}}\right)$ [57]. However, no specific receptor binding was found and a modification of the membrane lipid physical properties was proposed as being responsible for the activation (Fig. 3A) [57]. Indeed, $\mathrm{Ca}^{2+}$ signaling is generally considered to be a significant intracellular regulatory driver of the dynamic and complex metastatic cascade $[58,59]$.

\section{Prostate cancer}

Silencing of $\mathrm{P} 2 \mathrm{X}_{7}$ can inhibit migration and invasiveness of prostate cancer cells both in vitro and in vivo [31]. $\mathrm{P} 2 \mathrm{X}_{7}$ stimulation of cell invasion and metastasis in prostate cancer cells involves certain epithelial/mesenchymal transition (EMT)/invasion-related gene products such as Snail, E-cadherin, MMP-3, ERK1/2 and PI3K/Akt signaling pathways (Fig. 3B) $[60,61]$. In prostate tumors, overexpressed mouse orthologue cathelicidin-related AMP (CRAMP) initially chemo-attracts immature myeloid progenitors (IMPs) to the tumor microenvironment (TME) and mediates differentiation and polarization of early myeloid progenitors into protumorigenic type 2 (M2) macrophages to help drive prostate cancer progression [62]. The stimulation of $\mathrm{P} 2 \mathrm{X}_{7}$ can promote migration of PC9 lung cells and T47D breast cancer cells [30], suggesting involvement of a similar $\mathrm{P}_{2} \mathrm{X}_{7}$-based mechanism in other solid tumors [63]. $\mathrm{P} 2 \mathrm{X}_{7}$ can trigger massive release of vascular endothelial growth factor (VEGF) from immune cells as well as tumor cells [31].

\section{Pancreatic cancer}

The expression level of hCAP-18/LL-37 is high in the tumor stroma of advanced primary and secondary pancreatic ductal adenocarcinomas (PDACs) [30]. The K-Ras ${ }^{+/ L S L-G 12 D}$; Trp53 ${ }^{\text {LSL- }}$ R172H; PDX1-Cre mouse model (KPC) has been found to develop PDACs and metastases over 30 weeks $[30,64]$. Tumorigenesis can be dramatically inhibited by either reconstituting the KPC mice with bone marrow from cathelicidin-related antimicrobial peptide knockout mice or by pharmacologically inhibiting FPR2 and $\mathrm{P} 2 \mathrm{X}_{7}$ using the genetically engineered mouse model of pancreatic tumorigenesis [30].

Tumor-associated macrophages secrete hCAP-18/LL-37 in direct response to CSCsecreted Nodal/Activin-A/tumor growth factor- $\beta 1$ [30]. Recombinant LL-37 increases 
sphere-derived CSCmediated tumor formation and fitness, leading to enhanced growth and proliferation [30]. The established direct link between hCAP-18/LL37 and pancreatic CSCmediated tumorigenesis is critically important because CSCs are believed to be root of the tumors [30, 65-67]. It was also proposed that targeting pancreatic CSCs using inhibitors of the LL37 receptors could provide a possible therapeutic approach to block the tumor promoting cross-talk that exists within the tumor microenvironment [30]. Indeed, inhibitors against some LL-37 receptors, such as RTK or FPR2 inhibitor, have been used for therapeutic purposes and show promising effects [1, 42, 68-70].

\section{Malignant melanoma}

Immunohistochemical analyses showed that hCAP-18/LL-37 expression levels increased in malignant melanoma [71]. Recombinant LL-37

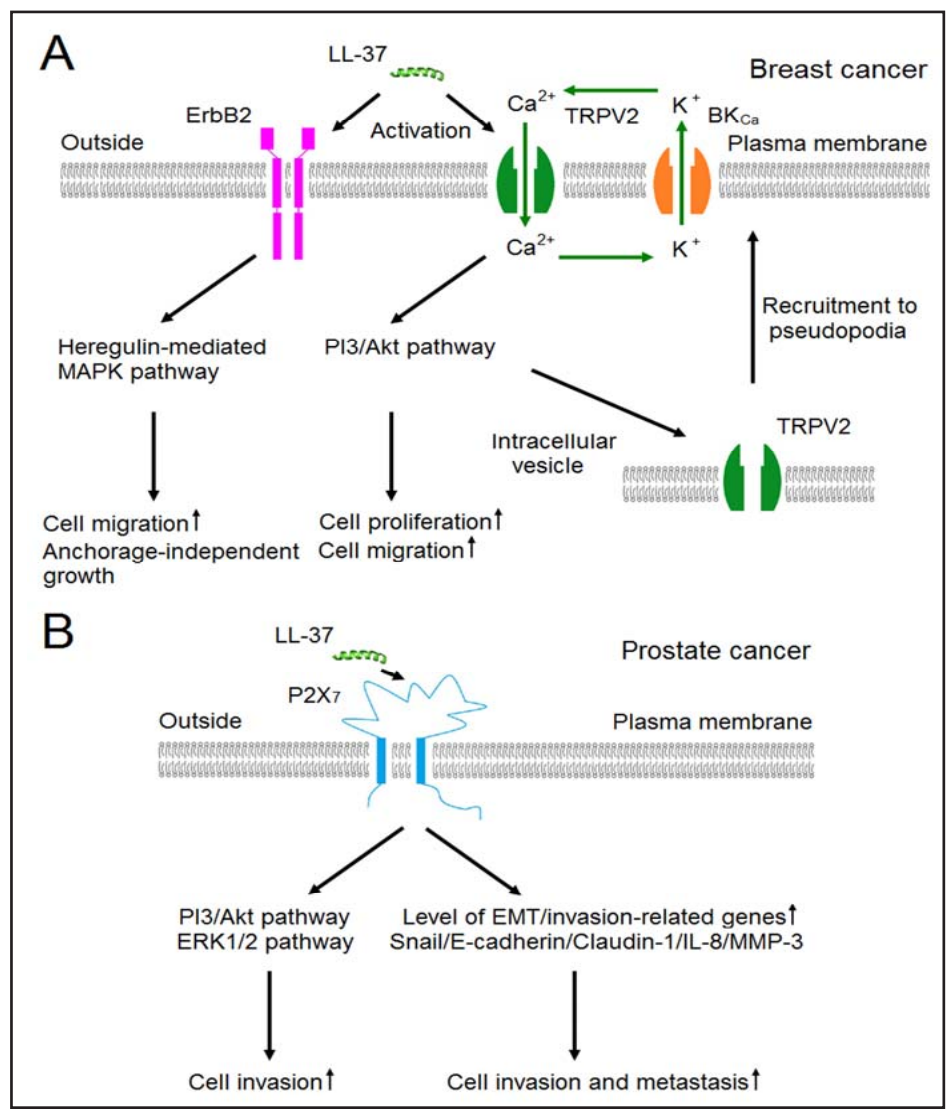

Fig. 3. Proposed tumorigenic mechanism of human cathelicidin LL-37 involvement in breast and prostate cancer cells. (A) Breast cancer. LL37 activates TRPV2 and then PI3/Akt signaling and PI3/Akt signaling induce recruitment of TRPV2 from intracellular vesicles to the plasma membrane of pseudopodia. $\mathrm{Ca}^{2+}$ entry through TRPV2 occurs in concert with $\mathrm{K}^{+}$efflux through $\mathrm{BK}_{\mathrm{Ca}}$ (B) Prostate cancer. ErbB2, Erb-b2 receptor tyrosine kinase 2. TRPV2, transient receptor potential cation. $\mathrm{BK}_{\mathrm{Ca}^{\prime}} \mathrm{Ca}^{2+}$-activated $\mathrm{K}^{+}$-channels. $\mathrm{P} 2 \mathrm{X}_{7}$, purinergic receptor 7. EMT, epithelial/mesenchymal transition. treatment could stimulate melanoma cell proliferation, migration and invasion in vitro [64]. TLR4 is vital to cell growth and migration in melanoma cells [72]. It was also suggested that LL-37, one of the agonists for TLR4, may promote melanoma progression through TLR4 signaling [73]. LL-37 may bind to gene promoter regions and modulate transcription in malignant melanoma [32]. Indeed, silencing hCAP-18/LL-37 gene in melanoma A375 cells alters expression of genes associated with cellular stress, histone, ubiquitination, metabolism, etc [32]. A recent report has indicated that LL-37 can upregulate Y-box binding protein-1 (YB-1) expression and activate the NF- $\kappa B$ signaling pathway to accelerate the malignant progression of the A375 and A875 MM cell lines, thus increasing tumor cell proliferation, migration and invasion [74].

Skin squamous cell carcinoma (SCC)

When serum-starved SCC A431 cells were treated with recombinant LL-37, the treatment promoted the proliferation and invasion of A431 cells by upregulating human DNA-binding protein A (dbpA) mRNA and protein expression [33, 34]. A431 cells treated by pyrollidine dithiocarbamate (PDTC), a transcription factor NF- $\mathrm{BB}$ inhibitor, were not susceptible to LL$37-$ driven induction of $\mathrm{dbpA}$ expression, showing that this process depends on the NF- $\mathrm{BB}$ signaling pathway $[33,34]$.

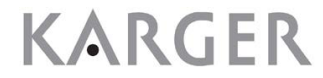




\section{Cellular Physiology Cell Physiol Biochem 2018;47:1060-1073 \begin{tabular}{l|l} 
DOI: 10.1159/000490183 & Ond Biochemistry 2018 The Author(s). Published by S. Karger AG, Basel \\
wwww.karger.com/cpb
\end{tabular}

\section{Anti-cancer effects}

In colon cancer, gastric cancer, hematologic malignancy and oral squamous cell carcinoma (OSCC), the LL-37 expression levels are downregulated compared to the normal tissues [2, 14, 24, 75-77]. These findings show that LL-37 can exert anti-cancer effects in these cancers.

\section{Colon cancer}

LL-37 is strongly expressed in normal colon mucosa but is downregulated in colon cancer tissues. The low LL-37 levels had been suggested to serve as a biomarker of colon cancer $[14,78]$. LL-37 is known to increase the level of pro-apoptotic Bax/Bak and reduce the level of anti-apoptotic $\mathrm{Bcl}-2$ [14]. LL-37 also increases the expression of PUMA and p53 $[2,14]$. PUMA is a direct target of p53 and a modulator of apoptosis in colon cancer cells (Fig. 4A) [14]. In colon cancer cells, the nuclear levels of apoptosis-inducing-factor (AIF) and endonuclease G (EndoG) are prominently induced by LL-37, resulting in caspase-independent apoptosis [14]. A LL-37-based mechanism that activates a GPCR-p53-Bax/Bak/ Bcl-2 signaling cascade to trigger AIF/ EndoG-mediated apoptosis was proposed in colon cancer cells (Fig. 4A) [14]. FK-16, a fragment of residues 17 to 32 of LL-37, upregulated the expression of LC3-I/II, Atg5 and Atg7, enabling formation of LC3-positive autophagosomes [15]. These observations show that FK-16 triggers caspase-independent apoptosis and autophagy through the p53-Bcl-2/Bax signaling in colon cancer cells (Fig. 4A) [2, 15]. Interestingly, the anti-cancer activity of LL-37 improved when attached to the surface of magnetic nanoparticles (MNPs) [79, 80].

Cathelicidin LL-37 effectively inhibits tumor growth factor- $\beta 1$-induced EMT of colon cancer cells and proliferation of fibroblast-supported colon cancer cell (Fig. 4A) [81]. MiR663a is a miRNA that undergoes major upregulation in HCT116 cells treated with either LL-37 or LL-37 analogue peptide FF/CAP18 (FRKSKEKIGKFFKRIVQRIFDFLRNLV) to drive anti-proliferative effects [82]. The anti-proliferative effect of miR-663a has been attributed to suppressed expression of CXC chemokine receptor type 4 (CXCR4), resulting in the abrogation of Akt phosphorylation and cell cycle arrest in $\mathrm{G}_{2} / \mathrm{M}$ via p21 activation in colon cancer cells (Fig. 4A) [82]. Treatment of HCT116 with FF/CAP18 exerts antiproliferative effects via a p53-independent mechanism [83]. The antiproliferative effects of FF/CAP18 are supported by clear-cut alterations in major metabolic pathways such as urine metabolism, glycolysis, and the TCA cycle in FF/CAP18-treated HCT116 cells [84].

\section{Gastric cancer}

In gastric cancer tissues, LL-37 expression level is considerably lower than that in noncancer adjacent tissues [75]. The anti-cancer effect of LL-37 has been proposed to involve 


\section{Cellular Physiology Cell Physiol Biochem 2018;47:1060-1073 \\ \begin{tabular}{c|c} 
DOI: 10.1159/000490183 & $\begin{array}{l}\text { O 2018 The Author(s). Published by S. Karger AG, Basel } \\
\text { www.karger.com/cpb }\end{array}$
\end{tabular} \\ Chen et al.: Mechanisms of LL-37 in Cancer}

regulation of proteasome activation via bone morphogentic protein (BMP) signaling [75, 85]. The BMP signaling triggers recruitment and phosphorylation of Smad 1/5/8 to form heterodimers with Smad4, and this Smads complex then upregulates the expression level of p21 ${ }^{\text {Waf1 }}[24,75]$. Using a BMP-independent pathway, lower levels of cyclin E2 can also be induced by LL-37 [75]. The alteration of p21 Waf1 and cyclin E2 expression levels can trigger $G_{0} / G_{1}$ phase cell cycle arrest (Fig. 4B) [75]. Taken together, these observations indicate that LL-37 inhibits gastric cancer cell proliferation through activation of BMP signaling via a proteasome-dependent mechanism (Fig. 4B) [75]. It has also been reported that the formyl peptide receptor 1 (FPR1) can act as a tumor suppressor in human gastric cancer by inhibiting angiogenesis (Fig. 4B) [86, 87].

\section{Hematologic malignancy}

The LL-37 expression level in the neutrophils of healthy individuals is significantly lower than that of patients with acute myeloid leukemia at the protein level, but not at the mRNA level [75]. Notably, recombinant LL-37 treatment reportedly kills Jurkat T leukemia cells by activating apoptosis that is caspase-independent but calpain- and AIF-dependent as shown by BAX activation and translocation to mitochondria (Fig. 5) $[2,88]$. Although LL-37 targeted receptor in Jurkat cells has not yet been reported, it is known that FPRL1, a LL-37targeted GPCR is expressed in T lymphocytes [89].

Cathelicidin secreted from inflammatory M1 macrophages has been shown to directly induce cell death by targeting mitochondria of high-grade lymphatic malignancies such as Burkitt's lymphoma (BL) cells [90]. Conversely, anti-inflammatory M2 macrophages and M2-like tumor-associated macrophages (TAMs) in BL affect vitamin D signaling, resulting in downregulation of hCAP-18/LL-37 and consequently, in inability to kill BL cells (Fig. 5) [90]. Mechanistically, the induction of the vitamin D signaling pathway activates TAM antitumor activity and improves the efficacy of antibody-dependent cellular cytotoxicity (ADCC) against BL cells (Fig. 5) [90]. Moreover, cathelicidin knockout mice (Camp ${ }^{-/}$) exhibit quicker tumor growth than wild types in two xenograft tumor mouse models (murine melanoma cell line B16.F10 and RMA-S cell line derived from T cell lymphoma of C57BL/6). NK cells derived from Camp $\%$ as compared to the wild types show impaired cytotoxic action toward tumor targets [91]. The findings indicate the significance of cathelicidin to NK cell function and in vivo tumor defense (Fig. 5) [91].

\section{Oral Squamous Cell Carcinoma (OSCC)}

Immunohistochemical analyses show that low expression of LL-37 in OSCC tissues compared to the normal oral mucosa tissues is related to histological differentiation and lymph node metastasis [77]. These results suggest that LL-37 might act as a tumor suppressor in OSCC [77]. The regulation of hCAP-18 expression in several oral cancer cell lines involves DNA methylation status at human CAMP promoter region [77]. It had also been shown that incubation of a C-terminal domain peptide of human CAP18 (109-135) induces caspase-independent apoptosis in OSCC SAS-H1 cells but not in human gingival fibroblasts or HaCaT cells [92].

Recent reports indicate that some cancer cells have cholesterol-rich lipid rafts, which could also be a key factor governing LL-37 selectivity for different cancer cells, thus providing a novel possibility besides the anti-cancer mechanisms of LL-37 already mentioned $[1,5,93$, 94].

Roles of vitamin D-dependent induction of cathelicidin in cancer progression

1, 25-Dihydroxyvitamin D3 $\left[1,25(\mathrm{OH})_{2} \mathrm{D}_{3}\right]$, the biologically active form of vitamin D induces expression of human CAMP [93-95]. The induction occurs via a consensus vitamin $\mathrm{D}$ response element (VDRE) in human CAMP promoter that is activated by vitamin D binding to the vitamin D receptor (VDR) [93-97]. Microorganisms such as Mycobacterium tuberculosis, induce expression of the VDR and vitamin D-1-hydroxylase genes in human macrophages, leading to the generation of more $1,25(\mathrm{OH})_{2} \mathrm{D}_{3}$, which in turn upregulates of hCAP18/LL- 
37 [98]. It has been reported that the VDR BsmI G/A gene variant might be a moderate risk factor for ovarian cancer in the European population [99]. The polymorphisms of vitamin D receptor gene BsmI and FokI may be related to ovarian cancer risk in Polish population [100]. The protective effects of vitamin $\mathrm{D}$ and VDR on colorectal cancer and the association of vitamin D deficiency with the high risk of colorectal cancer have been also reported [101-105]. These findings suggested possible roles of vitamin D-dependent induction of cathelicidin in cancer progression. Indeed, such roles have been reported in a recent publication, which indicated that the vitamin D signaling pathway activation in human macrophages induces the anticancer activity of TAMs and enhances the efficacy of ADCC for high-grade lymphatic malignancies such as BL (Fig. 5) [90]. Another report also showed that the versican V1 derived from tumor cells enhances hCAP18/LL-37 expression in macrophages through the activation of TLR2 and subsequent vitamin D-dependent mechanisms to promote ovarian cancer progression in vitro [42]. Taken together, these findings strongly support the critical roles of vitamin D-dependent induction of cathelicidin in cancer progression.

\section{Conclusions and future perspectives}

Current research about the roles and mechanisms of LL-37 in human cancer mainly focuses on molecular and cellular levels. These investigations indicate that LL-37 can either be pro-tumorigenic or an anti-cancer agent for different cancers. Currently, it is difficult to fully understand the molecular basis for LL-37 effects in different cellular settings. However, available data indicate that LL-37 can act as a ligand for various membrane receptors thus explaining its tissue-specific effects in different cancers. Although mouse models of cancer for studying the mechanism of CAMP/LL-37 have been used [30, 41, 43, 62, 64, 81, 91, 106, 107], the promoter of murine cathelicidin gene lacks of VDRE. Thus, the signaling of vitamin D-dependent induction of cathelicidin does not work effectively in mouse cells $[95,108]$. Differences in tissue-specific and developmental expression of cathelicidin between human 
and mouse also exist $[109,110]$. Due to the problems and differences, it can be concluded that results obtained from mouse models are defective to explain the roles of CAMP/LL-37 in human cancer progression. Based on the growing number of novel proposed mechanisms of tumorigenic and anti-cancer effects induced by LL-37, it is reasonable to conclude that LL-37 exerts multiple and complex effects on various cancer cells. In some cancers, there are both tumorigenic and anti-cancer effects induced by LL-37, and the final effect depends on the combined effects of these involved mechanisms.

More and more tumor types are now associated with LL-37, and we suggest the need for further exploration of the relationship between LL-37 and other cancers not yet investigated. Considering the fact that the expression of LL-37 in various cells is inducible, the relationship between these inducible factors and tumorigenesis needs to be considered and investigated. The anti-cancer effect of vitamin D in several cancers is intriguing and promising. The detailed mechanisms of vitamin D-dependent induction of cathelicidin that can impact cancer progression need to be further clarified. As a result of the elucidation of the roles and mechanisms of LL-37 in human cancer, it is expected that the research of LL-37 on therapeutic purpose for cancers will increase.

\section{Acknowledgements}

This research was supported by grants from the National Natural Science Foundation of China (No. 81760490; 81560185) and Natural Science Foundation of Guangxi (2017GXNSFAA198239). We would like to thank Prof. Rhoderick E. Brown at Hormel Institute, University of Minnesota, for English editing of the manuscript.

\section{Disclosure Statement}

No conflict of interests exists.

\section{References}

1 Kuroda K, Okumura K, Isogai $\mathrm{H}$, Isogai $\mathrm{E}$ : The human cathelicidin antimicrobial peptide LL-37 and mimics are potential anti-cancer drugs. Front Oncol 2015;5:144.

2 Piktel E, Niemirowicz K, Wnorowska U, Wątek M, Wollny T, Głuszek K, Góźdź S, Levental I, Bucki R: The role of cathelicidin LL-37 in cancer development. Arch Immunol Ther Exp (Warsz) 2016;64:33-46.

3 Bandurska K, Berdowska A, Barczyńska-Felusiak R, Krupa P: Unique features of human cathelicidin LL-37. Biofactors 2015;41:289-300.

4 Xhindoli D, Pacor S, Benincasa M, Scocchi M, Gennaro R, Tossi A: The human cathelicidin LL-37-A poreforming antibacterial peptide and host-cell modulator. Biochim Biophys Acta 2016;1858:546-566.

5 Vandamme D, Landuyt B, Luyten W, Schoofs L: A comprehensive summary of LL-37, the factotum human cathelicidin peptide. Cell Immunol 2012;280:22-35.

6 Pachón-Ibáñez ME, Smani Y, Pachón J, Sánchez-Céspedes J: Perspectives for clinical use of engineered human host defense antimicrobial peptides. FEMS Microbiol Rev 2017;41:323-342.

7 Gaffen SL, Herzberg MC, Taubman MA, Van Dyke TE: Recent advances in host defense mechanisms/ therapies against oral infectious diseases and consequences for systemic disease. Adv Dent Res 2014;26:30-37.

8 Ávila EE, Salaiza N, Pulido J, Rodríguez MC, Díaz-Godínez C, Laclette JP, Becker I, Carrero JC: Entamoeba histolytica trophozoites and lipopeptidophosphoglycan trigger human neutrophil extracellular traps. PLoS One 2016;11:e0158979.

-9 Alagarasu K, Patil PS, Shil P, Seervi M, Kakade MB, Tillu H, Salunke A: In-vitro effect of human cathelicidin antimicrobial peptide LL-37 on dengue virus type 2. Peptides 2017;92:23-30.

10 Dosler S, Karaaslan E: Inhibition and destruction of Pseudomonas aeruginosa biofilms by antibiotics and antimicrobial peptides. Peptides 2014;62:32-37.

11 Luo Y, McLean DT, Linden GJ, McAuley DF, McMullan R, Lundy FT: The Naturally Occurring Host Defense Peptide, LL-37, and its truncated mimetics KE-18 and KR-12 have selected biocidal and antibiofilm activities against Candida albicans, Staphylococcus aureus, and Escherichia coli In vitro. Front Microbiol $2017 ; 8: 544$. 


\section{Cellular Physiology Cell Physiol Biochem 2018;47:1060-1073 \begin{tabular}{l|l} 
DOI: 10.1159/000490183 & O 2018 The Author(s). Published by S. Karger AG, Basel \\
www.karger.com/cpb
\end{tabular} \\ Chen et al.: Mechanisms of LL-37 in Cancer}

-12 Shaykhiev R, Beisswenger C, Kändler K, Senske J, Püchner A, Damm T, Behr J, Bals R: Human endogenous antibiotic LL-37 stimulates airway epithelial cell proliferation and wound closure. Am J Physiol Lung Cell Mol Physiol 2005;289:L842-848.

13 Kim SH, Kim YN, Jang YS: Cutting Edge: LL-37-mediated formyl peptide receptor-2 signaling in follicular dendritic cells contributes to b cell activation in Peyer's patch germinal centers. J Immunol 2017;198:629633.

14 Tuomela JM, Sandholm JA, Kaakinen M, Hayden KL, Haapasaari KM, Jukkola-Vuorinen A, Kauppila JH, Lehenkari PP, Harris KW, Graves DE, Selander KS: Telomeric G-quadruplex-forming DNA fragments induce TLR9-mediated and LL-37-regulated invasion in breast cancer cells in vitro. Breast Cancer Res Treat 2016;155:261-271.

15 Ren SX, Cheng AS, To KF, Tong JH, Li MS, Shen J, Wong CC, Zhang L, Chan RL, Wang XJ, Ng SS, Chiu LC, Marquez VE, Gallo RL, Chan FK, Yu J, Sung JJ, Wu WK, Cho CH: Host immune defense peptide LL-37 activates caspase-independent apoptosis and suppresses colon cancer. Cancer Res 2012;72:6512-6523.

16 Ren SX, Shen J, Cheng AS, Lu L, Chan RL, Li ZJ, Wang XJ, Wong CC, Zhang L, Ng SS, Chan FL, Chan FK, Yu J, Sung JJ, Wu WK, Cho CH: FK-16 derived from the anti-cancer peptide LL-37 induces caspase-independent apoptosis and autophagic cell death in colon cancer cells. PLoS One 2013;8:e63641.

17 Brown KL, Poon GF, Birkenhead D, Pena OM, Falsafi R, Dahlgren C, Karlsson A, Bylund J, Hancock RE, Johnson P: Host defense peptide LL-37 selectively reduces proinflammatory macrophage responses. J Immunol 2011;186:5497-5505.

-18 Medina Santos CE, López Hurtado CN, Rivas Santiago B, Gonzalez-Amaro R, Cataño Cañizales YG, Martínez Fierro ML, Enciso-Moreno JA, García Hernández MH: LL-37, HNP-1, and HBD2/3 modulate the secretion of cytokines TNF- $\alpha$, IL-6, IFN- $\gamma$, IL-10 and MMP1 in human primary cell cultures. Eur Cytokine Netw 2016;27:68-74.

19 Byfield FJ, Kowalski M, Cruz K, Leszczyńska K, Namiot A, Savage PB, Bucki R, Janmey PA: Cathelicidin LL37 increases lung epithelial cell stiffness, decreases transepithelial permeability, and prevents epithelial invasion by Pseudomonas aeruginosa. J Immunol 2011; 187:6402-6409.

20 Coffelt SB, Marini FC, Watson K, Zwezdaryk KJ, Dembinski JL, LaMarca HL, Tomchuck SL, Honer zu Bentrup K, Danka ES, Henkle SL, Scandurro AB: The pro-inflammatory peptide LL-37 promotes ovarian tumor progression through recruitment of multipotent mesenchymal stromal cells. Proc Natl Acad Sci USA 2009;106:3806-3811.

21 Wuerth K, Hancock RE: New insights into cathelicidin modulation of adaptive immunity. Eur J Immunol 2011;41:2817-2819.

22 Fabisiak A, Murawska N, Fichna J: LL-37: Cathelicidin-related antimicrobial peptide with pleiotropic activity. Pharmacol Rep 2016;68:802-808.

-23 Salvado MD, Di Gennaro A, Lindbom L, Agerberth B, Haeggström JZ: Cathelicidin LL-37 induces angiogenesis via PGE2-EP3 signaling in endothelial cells, in vivo inhibition by aspirin. Arterioscler Thromb Vasc Biol 2013;33:1965-1972.

24 Wu WK, Wang G, Coffelt SB, Betancourt AM, Lee CW, Fan D, Wu K, Yu J, Sung JJ, Cho CH: Emerging roles of the host defense peptide LL-37 in human cancer and its potential therapeutic applications. Int J Cancer 2010;127:1741-1747.

-25 Hancock RE, Haney EF, Gill EE: The immunology of host defence peptides: beyond antimicrobial activity. Nat Rev Immunol 2016;16:321-334.

26 Verjans ET, Zels S, Luyten W, Landuyt B, Schoofs L: Molecular mechanisms of LL-37-induced receptor activation: An overview. Peptides 2016;85:16-26.

-27 Jiménez-Dalmaroni MJ, Gerswhin ME, Adamopoulos IE: The critical role of toll-like receptors--From microbial recognition to autoimmunity: A comprehensive review. Autoimmun Rev 2016;15:1-8.

-28 Leifer CA, Medvedev AE: Molecular mechanisms of regulation of Toll-like receptor signaling. J Leukoc Biol 2016;100:927-941.

29 Mookherjee N, Lippert DN, Hamill P, Falsafi R, Nijnik A, Kindrachuk J, Pistolic J, Gardy J, Miri P, Naseer M, Foster LJ, Hancock RE: Intracellular receptor for human host defense peptide LL-37 in monocytes. J Immunol 2009;183:2688-2696.

-30 Sainz B Jr, Alcala S, Garcia E, Sanchez-Ripoll Y, Azevedo MM, Cioffi M, Tatari M, Miranda-Lorenzo I, Hidalgo M, Gomez-Lopez G, Cañamero M, Erkan M, Kleeff J, García-Silva S, Sancho P, Hermann PC, Heeschen C: Microenvironmental hCAP-18/LL-37 promotes pancreatic ductal adenocarcinoma by activating its cancer stem cell compartment. Gut 2015;64:1921-1935. 


\section{Cellular Physiology Cell Physiol Biochem 2018;47:1060-1073 \begin{tabular}{l|l} 
DOI: 10.1159/000490183 & Ond Biochemistry \\
Published online: May 30, 2018 & $\begin{array}{l}\text { 2018 The Author(s). Published by S. Karger AG, Basel } \\
\text { www.karger.com/cpb }\end{array}$
\end{tabular} \\ Chen et al.: Mechanisms of LL-37 in Cancer}

31 Di Virgilio F, Falzoni S, Giuliani AL, Adinolfi E: P2 receptors in cancer progression and metastatic spreading. Curr Opin Pharmacol 2016;29:17-25.

-32 Muñoz M, Craske M, Severino P, de Lima TM, Labhart P, Chammas R, Velasco IT, Machado MC, Egan B, Nakaya HI, Pinheiro da Silva F: Antimicrobial peptide LL-37 participates in the transcriptional regulation of melanoma cells. J Cancer 2016;7:2341-2345.

-33 Wang W, Jia J, Li C, Duan Q Yang J, Wang X, Li R, Chen C, Yan H, Zheng Y: Antimicrobial peptide LL-37 promotes the proliferation and invasion of skin squamous cell carcinoma by upregulating DNA-binding protein A. Oncol Lett 2016;12:1745-1752.

-34 Wang W, Zheng Y, Jia J, Li C, Duan Q, Li R, Wang X, Shao Y, Chen C, Yan H: Antimicrobial peptide LL-37 promotes the viability and invasion of skin squamous cell carcinoma by upregulating YB-1. Exp Ther Med 2017;14:499-506.

-35 Coffelt SB,Waterman RS,Florze L,Höner zu Bentrup K, Zwezdaryk KJ, Tomchuck SL, LaMarca HL, Danka ES, Morris CA, Scandurro AB: Ovarian cancers overexpress the antimicrobial protein hCAP-18 and its derivative LL-37 increases ovarian cancer cell proliferation and invasion. Int J Cancer 2008;122:10301039.

-36 Coffelt SB, Marini FC, Watson K, Zwezdaryk KJ, Dembinski JL, LaMarca HL, Tomchuck SL, Honer zu Bentrup K, Danka ES, Henkle SL, Scandurro AB: The pro-inflammatory peptide LL-37 promotes ovarian tumor progression through recruitment of multipotent mesenchymal stromal cells. Proc Natl Acad Sci USA 2009;106:3806-3811.

37 Malemud CJ: Matrix metalloproteinases (MMPs) in health and disease: an overview. Front Biosci 2006;11:1696-1701.

38 Lazennec G, Lam PY: Recent discoveries concerning the tumor - mesenchymal stem cell interactions. Biochim Biophys Acta 2016;1866:290-299.

-39 Touboul C, Vidal F, Pasquier J, Lis R, Rafii A: Role of mesenchymal cells in the natural history of ovarian cancer: a review. J Transl Med 2014;12:271.

-40 Hsu HS, Lin JH, Hsu TW, Su K, Wang CW, Yang KY, Chiou SH, Hung SC: Mesenchymal stem cells enhance lung cancer initiation through activation of IL-6/JAK2/STAT3 pathway. Lung Cancer 2012;75:167-177.

41 Chuang CM, Monie A, Wu A, Mao CP, Hung CF: Treatment with LL-37 peptide enhances antitumor effects induced by CpG oligodeoxynucleotides against ovarian cancer. Hum Gene Ther 2009;20:303-313.

42 Li D, Wang X, Wu JL, Quan WQ, Ma L, Yang F, Wu KY, Wan HY: Tumor-produced versican V1 enhances hCAP18/LL-37 expression in macrophages through activation of TLR2 and vitamin D3 signaling to promote ovarian cancer progression in vitro. PLoS One 2013;8:e56616.

-43 Li D, Beisswenger C, Herr C, Schmid RM, Gallo RL, Han G, Zakharkina T, Bals R: Expression of the antimicrobial peptide cathelicidin in myeloid cells is required for lung tumor growth. Oncogene 2014;33:2709-2716.

-44 Elliott LA, Doherty GA, Sheahan K, Ryan EJ: Human tumor-infiltrating myeloid cells: phenotypic and functional diversity. Front Immunol 2017;8:86.

45 Cui R, Yue W, Lattime EC, Stein MN, Xu Q, Tan XL: Targeting tumor-associated macrophages to combat pancreatic cancer. Oncotarget 2016;7:50735-50754.

46 von Haussen J, Koczulla R, Shaykhiev R, Herr C, Pinkenburg O, Reimer D, Wiewrodt R, Biesterfeld S, Aigner A, Czubayko F, Bals R: The host defence peptide LL-37/hCAP-18 is a growth factor for lung cancer cells. Lung Cancer 2008;59:12-23.

47 Tokumaru S, Sayama K, Shirakata Y, Komatsuzawa H, Ouhara K, Hanakawa Y, Yahata Y, Dai X, Tohyama M, Nagai H, Yang L, Higashiyama S, Yoshimura A, Sugai M, Hashimoto K: Induction of keratinocyte migration via transactivation of the epidermal growth factor receptor by the antimicrobial peptide LL-37. J Immunol 2005;175:4662-4668.

-48 Tjabringa GS, Aarbiou J, Ninaber DK, Drijfhout JW, Sørensen OE, Borregaard N, Rabe KF, Hiemstra PS: The antimicrobial peptide LL-37 activates innate immunity at the airway epithelial surface by transactivation of the epidermal growth factor receptor. J Immunol 2003;171:6690-6696.

49 Hong JT, Son DJ, Lee CK, Yoon DY, Lee DH, Park MH: Interleukin 32, inflammation and cancer. Pharmacol Ther 2017;174:127-137.

-50 Zeng Q, Li S, Zhou Y, Ou W, Cai X, Zhang L, Huang W, Huang L, Wang Q: Interleukin-32 contributes to invasion and metastasis of primary lung adenocarcinoma via NF-kappaB induced matrix metalloproteinases 2 and 9 expression. Cytokine 2014;65:24-32. 


\section{Cellular Physiology Cell Physiol Biochem 2018;47:1060-1073 \begin{tabular}{l|l} 
DOI: 10.1159/000490183 & Ond Biochemistry \\
Published online: May 30, 2018 & $\begin{array}{l}\text { 2018 The Author(s). Published by S. Karger AG, Basel } \\
\text { www.karger.com/cpb }\end{array}$
\end{tabular} \\ Chen et al.: Mechanisms of LL-37 in Cancer}

51 Choi KY, Napper S, Mookherjee N: Human cathelicidin LL-37 and its derivative IG-19 regulate interleukin32-induced inflammation. Immunology 2014;143:68-80.

52 Heilborn JD, Nilsson MF, Jimenez CI, Sandstedt B, Borregaard N, Tham E, Sørensen OE, Weber G, Ståhle M: Antimicrobial protein hCAP18/LL-37 is highly expressed in breast cancer and is a putative growth factor for epithelial cells. Int J Cancer 2005;114:713-719.

-53 Carmona FJ, Montemurro F, Kannan S, Rossi V, Verma C, Baselga J, Scaltriti M: AKT signaling in ERBB2amplified breast cancer. Pharmacol Ther 2016;158:63-70.

54 Farabaugh SM, Chan BT, Cui X, Dearth RK, Lee AV: Lack of interaction between ErbB2 and insulin receptor substrate signaling in breast cancer. Cell Commun Signal 2016;14:25.

-55 Sacco AG, Worden FP: Molecularly targeted therapy for the treatment of head and neck cancer: a review of the ErbB family inhibitors. Onco Targets Ther 2016;9:1927-1943.

-56 Weber G, Chamorro CI, Granath F, Liljegren A, Zreika S, Saidak Z, Sandstedt B, Rotstein S, Mentaverri R, Sánchez F, Pivarcsi A, Ståhle M: Human antimicrobial protein hCAP18/LL-37 promotes a metastatic phenotype in breast cancer. Breast Cancer Res 2009;11:R6.

57 Gambade A, Zreika S, Guéguinou M, Chourpa I, Fromont G, Bouchet AM, Burlaud-Gaillard J, PotierCartereau M, Roger S, Aucagne V, Chevalier S, Vandier C, Goupille C, Weber G: Activation of TRPV2 and BKCa channels by the LL-37 enantiomers stimulates calcium entry and migration of cancer cells. Oncotarget 2016;7:23785-23800.

58 Iamshanova 0, Fiorio Pla A, Prevarskaya N: Molecular mechanisms of tumour invasion: regulation by calcium signals. J Physiol 2017;595:3063-3075.

59 Fleig A, Parekh AB: New insights into $\mathrm{Ca}^{2+}$ channel function in health and disease. J Physiol 2017;595:29972998.

60 Hensel JA, Chanda D, Kumar S, Sawant A, Grizzle WE, Siegal GP, Ponnazhagan S: LL-37 as a therapeutic target for late stage prostate cancer. Prostate 2011;71:659-670.

61 Qiu Y, Li WH, Zhang HQ, Liu Y, Tian XX, Fang WG: P2X7 mediates ATP-driven invasiveness in prostate cancer cells. PLoS One 2014;9:e114371.

62 Cha HR, Lee JH, Hensel JA, Sawant AB, Davis BH, Lee CM, Deshane JS, Ponnazhagan S: Prostate cancerderived cathelicidin-related antimicrobial peptide facilitates macrophage differentiation and polarization of immature myeloid progenitors to protumorigenic macrophages. Prostate 2016;76:624-636.

63 Roger S, Jelassi B, Couillin I, Pelegrin P, Besson P, Jiang LH: Understanding the roles of the P2X7 receptor in solid tumour progression and therapeutic perspectives. Biochim Biophys Acta 2015;1848:2584-2602.

-64 Hingorani SR, Wang L, Multani AS, Combs C, Deramaudt TB, Hruban RH, Rustgi AK, Chang S, Tuveson DA:Trp53R172H and KrasG12D cooperate to promote chromosomal instability and widely metastatic pancreatic ductal adenocarcinoma in mice. Cancer Cell 2005;7:469-483.

65 Reya T, Morrison SJ, Clarke MF, Weissman IL: Stem cells, cancer, and cancer stem cells. Nature 2001;414:105-111.

-66 Zhou AD, Diao LT, Xu H, Xiao ZD, Li JH, Zhou H, Qu LH: $\beta$-Catenin/LEF1 transactivates the microRNA-371-373 cluster that modulates the Wnt/ $\beta$-catenin-signaling pathway. Oncogene 2012;31:29682978.

67 Nassar D, Blanpain C: Cancer Stem Cells: Basic Concepts and Therapeutic Implications. Annu Rev Pathol 2016;11:47-76.

68 Vincenzi B, Imperatori M, Silletta M, Marrucci E, Santini D, Tonini G: Emerging kinase inhibitors of the treatment of gastric cancer. Expert Opin Emerg Drugs 2015;20:479-493.

69 Byrne AT, Alférez DG, Amant F, Annibali D, Arribas J, Biankin AV, Bruna A, Budinská E, Caldas C, Chang DK, Clarke RB, Clevers H, Coukos G, Dangles-Marie V, Eckhardt SG, Gonzalez-Suarez E, Hermans E, Hidalgo M, Jarzabek MA, de Jong S, Jonkers J, Kemper K, Lanfrancone L, Mælandsmo GM, Marangoni E, Marine JC, Medico E, Norum JH, Palmer HG, Peeper DS, Pelicci PG, Piris-Gimenez A, Roman-Roman S, Rueda OM, Seoane J, Serra V, Soucek L, Vanhecke D, Villanueva A, Vinolo E, Bertotti A, Trusolino L: Interrogating open issues in cancer precision medicine with patient-derived xenografts. Nat Rev Cancer 2017;17:254-268.

70 Cha HR, Hensel J, Ponnazhagan S: Prostate cancer cell-derived cathelicidin-related antimicrobial peptide regulates MCP-1 and CXCL1/2 through autocrine signaling. Cancer Res 2015; 75 (15 Suppl):Abstract nr 434. DOI:10.1158/1538-7445.AM2015-434.

-71 Kim JE, Kim HJ, Choi JM, Lee KH, Kim TY, Cho BK, Jung JY, Chung KY, Cho D, Park HJ: The antimicrobial peptide human cationic antimicrobial protein-18/cathelicidin LL-37 as a putative growth factor for malignant melanoma. Br J Dermatol 2010;163:959-967. 


\section{Cellular Physiology Cell Physiol Biochem 2018;47:1060-1073 \begin{tabular}{l|l} 
DOI: 10.1159/000490183 & Ond Biochemistry \\
Published online: May 30, 2018 & $\begin{array}{l}\text { 2018 The Author(s). Published by S. Karger AG, Basel } \\
\text { www.karger.com/cpb }\end{array}$
\end{tabular} \\ Chen et al.: Mechanisms of LL-37 in Cancer}

72 Takazawa Y, Kiniwa Y, Ogawa E, Uchiyama A, Ashida A, Uhara H, Goto Y, Okuyama R: Toll-like receptor 4 signaling promotes the migration of human melanoma cells. Tohoku J Exp Med 2014;234:57-65.

73 Mookherjee N, Brown KL, Bowdish DM, Doria S, Falsafi R, Hokamp K, Roche FM, Mu R, Doho GH, Pistolic J, Powers JP, Bryan J, Brinkman FS, Hancock RE: Modulation of the TLR-mediated inflammatory response by the endogenous human host defense peptide LL-37. J Immunol 2006;176:2455-2464.

74 Jia J, Zheng Y, Wang W, Shao Y, Li Z, Wang Q Wang Y, Yan H: Antimicrobial peptide LL-37 promotes YB-1 expression, and the viability, migration and invasion of malignant melanoma cells. Mol Med Rep 2017;15:240-248.

-75 Wu WK, Sung JJ, To KF, Yu L, Li HT, Li ZJ, Chu KM, Yu J, Cho CH: The host defense peptide LL-37 activates the tumor-suppressing bone morphogenetic protein signaling via inhibition of proteasome in gastric cancer cells. J Cell Physiol 2010;223:178-186.

76 An LL, Ma XT, Yang YH, Lin YM, Song YH, Wu KF: Marked reduction of LL-37/hCAP-18, an antimicrobial peptide, in patients with acute myeloid leukemia. Int J Hematol 2005;81:45-7.

-77 Chen X, Qi G, Qin M, Zou Y, Zhong K, Tang Y, Guo Y, Jiang X, Liang L, Zou X: DNA methylation directly downregulates human cathelicidin antimicrobial peptide gene (CAMP) promoter activity. Oncotarget 2017;8:27943-27952.

78 Lim R, Lappas M, Riley C, Borregaard N, Moller HJ, Ahmed N, Rice GE: Investigation of human cationic antimicrobial protein-18 (hCAP-18), lactoferrin and CD163 as potential biomarkers for ovarian cancer. J Ovarian Res 2013;6:5.

-79 Niemirowicz K, Prokop I, Wilczewska AZ, Wnorowska U, Piktel E, Wątek M, Savage PB, Bucki R: Magnetic nanoparticles enhance the anti-cancer activity of cathelicidin LL-37 peptide against colon cancer cells. Int J Nanomedicine 2015;10:3843-3853.

80 Niemirowicz K, Durnaś B, Tokajuk G, Piktel E, Michalak G, Gu X, Kułakowska A, Savage PB, Bucki R: Formulation and candidacidal activity of magnetic nanoparticles coated with cathelicidin LL-37 and ceragenin CSA-13. Sci Rep 2017;7:4610.

-81 Cheng M, Ho S, Yoo JH, Tran DH, Bakirtzi K, Su B, Tran DH, Kubota Y, Ichikawa R, Koon HW: Cathelicidin suppresses colon cancer development by inhibition of cancer associated fibroblasts. Clin Exp Gastroenterol 2015;8:13-29.

82 Kuroda K, Fukuda T, Krstic-Demonacos M, Demonacos C, Okumura K, Isogai H, Hayashi M, Saito K, Isogai E: miR-663a regulates growth of colon cancer cells, after administration of antimicrobial peptides, by targeting CXCR4-p21 pathway. BMC Cancer 2017;17:33.

83 Kuroda K, Fukuda T, Yoneyama H, Katayama M, Isogai H, Okumura K, Isogai E: Anti-proliferative effect of an analogue of the LL-37 peptide in the colon cancer derived cell line HCT116 p53+/+ and p53-/-. Oncol Rep 2012;28:829-834.

-84 Kuroda K, Fukuda T, Isogai H, Okumura K, Krstic-Demonacos M, Isogai E: Antimicrobial peptide FF/CAP18 induces apoptotic cell death in HCT116 colon cancer cells via changes in the metabolic profile. Int J Oncol 2015;46:1516-1526.

85 Wu WK, Cho CH, Lee CW, Wu K, Fan D, Yu J, Sung JJ: Proteasome inhibition: a new therapeutic strategy to cancer treatment. Cancer Lett 2010;293:15-22.

86 Prevete N, Liotti F, Visciano C, Marone G, Melillo RM, de Paulis A: The formyl peptide receptor 1 exerts a tumor suppressor function in human gastric cancer by inhibiting angiogenesis. Oncogene 2015;34:38263838.

87 Li L, Chen K, Xiang Y, Yoshimura T, Su S, Zhu J, Bian XW, Wang JM: New development in studies of formylpeptide receptors: critical roles in host defense. J Leukoc Biol 2016;99:425-435.

88 Mader JS, Mookherjee N, Hancock RE, Bleackley RC: The human host defense peptide LL-37 induces apoptosis in a calpain- and apoptosis-inducing factor-dependent manner involving Bax activity. Mol Cancer Res 2009;7:689-702.

89 Yang D, Chertov 0, Oppenheim JJ: Participation of mammalian defensins and cathelicidins in antimicrobial immunity: receptors and activities of human defensins and cathelicidin (LL-37). J Leukoc Biol 2001;69:691-697.

-90 Bruns H, Büttner M, Fabri M, Mougiakakos D, Bittenbring JT, Hoffmann MH, Beier F, Pasemann S, Jitschin R, Hofmann AD, Neumann F, Daniel C, Maurberger A, Kempkes B, Amann K, Mackensen A, Gerbitz A: Vitamin D-dependent induction of cathelicidin in human macrophages results in cytotoxicity against high-grade $B$ cell lymphoma. Sci Transl Med 2015;7:282ra47. 


\section{Cellular Physiology Cell Physiol Biochem 2018;47:1060-1073 \begin{tabular}{l|l} 
DOI: 10.1159/000490183 & O 2018 The Author(s). Published by S. Karger AG, Basel \\
www.karger.com/cpb
\end{tabular} \\ Chen et al.: Mechanisms of LL-37 in Cancer}

-91 Büchau AS, Morizane S, Trowbridge J, Schauber J, Kotol P, Bui JD, Gallo RL: The host defense peptide cathelicidin is required for NK cell-mediated suppression of tumor growth. J Immunol 2010;184:369-378.

$\$ 92$ Okumura K, Itoh A, Isogai E, Hirose K, Hosokawa Y, Abiko Y, Shibata T, Hirata M, Isogai H: C-terminal domain of human CAP18 antimicrobial peptide induces apoptosis in oral squamous cell carcinoma SAS-H1 cells. Cancer Lett 2004;212:185-194.

\$3 Suzuki K, Murakami T, Hu Z, Tamura H, Kuwahara-Arai K, Iba T, Nagaoka I: Human host defense cathelicidin peptide ll-37 enhances the lipopolysaccharide uptake by liver sinusoidal endothelial cells without cell activation. J Immunol 2016;196:1338-1347.

-94 Tang X, Basavarajappa D, Haeggström JZ, Wan M: P2X7 receptor regulates internalization of antimicrobial peptide ll-37 by human macrophages that promotes intracellular pathogen clearance. J Immunol 2015;195:1191-1201.

95 Gombart AF, Borregaard N, Koeffler HP: Human cathelicidin antimicrobial peptide (CAMP) gene is a direct target of the vitamin $\mathrm{D}$ receptor and is strongly up-regulated in myeloid cells by 1, 25-dihydroxyvitamin D3. FASEB J 2005;19:1067-1077.

-96 Dai X, Sayama K, Tohyama M, Shirakata Y, Hanakawa Y, Tokumaru S, Yang L, Hirakawa S, Hashimoto K: PPAR $\gamma$ mediates innate immunity by regulating the $1 \alpha, 25$-dihydroxyvitamin D3 induced hBD-3 and cathelicidin in human keratinocytes. J Dermatol Sci 2010;60:179-186.

-97 Park K, Elias PM, Oda Y, Mackenzie D, Mauro T, Holleran WM, Uchida Y: Regulation of cathelicidin antimicrobial peptide expression by an endoplasmic reticulum (ER) stress signaling, vitamin D receptorindependent pathway. J Biol Chem 2011;286:34121-34130.

-98 Liu PT, Stenger S, Li H, Wenzel L, Tan BH, Krutzik SR, Ochoa MT, Schauber J, Wu K, Meinken C, Kamen DL, Wagner M, Bals R, Steinmeyer A, Zügel U, Gallo RL, Eisenberg D, Hewison M, Hollis BW, Adams JS, Bloom BR, Modlin RL: Toll-like receptor triggering of a vitamin D-mediated human antimicrobial response. Science 2006;311:1770-1773.

-99 Qin X, Lu Y, Qin A, Chen Z, Peng Q, Deng Y, Xie L, Wang J, Li R, Zeng J, Li S, Zhao J: Vitamin D receptor BsmI polymorphism and ovarian cancer risk: a meta-analysis. Int J Gynecol Cancer 2013;23:1178-1183.

100 Mostowska A, Sajdak S, Pawlik P, Lianeri M, Jagodzinski PP: Vitamin D receptor gene BsmI and FokI polymorphisms in relation to ovarian cancer risk in the Polish population. Genet Test Mol Biomarkers 2013;17:183-187.

101 Pereira F, Larriba MJ, Muñoz A: Vitamin D and colon cancer. Endocr Relat Cancer 2012;19:R51-71.

102 Sun J: The Role of Vitamin D and Vitamin D receptors in colon cancer. Clin Transl Gastroenterol 2017;8:e103.

103 Hightower JM, Dalessandri KM, Pope K, Hernández GT: Low 25-Hydroxyvitamin D and myofascial pain: association of cancer, colon polyps, and tendon rupture. J Am Coll Nutr 2017;36:455-461.

104 Zhu Y, Wang PP, Zhai G, Bapat B, Savas S, Woodrow JR, Sharma I, Li Y, Zhou X, Yang N, Campbell PT, Dicks E, Parfrey PS, Mclaughlin JR: Vitamin D receptor and calcium-sensing receptor polymorphisms and colorectal cancer survival in the Newfoundland population. Br J Cancer 2017;117:898-906.

105 Gandini S, Gnagnarella P, Serrano D, Pasquali E, Raimondi S: Vitamin D receptor polymorphisms and cancer. Adv Exp Med Biol 2014;810:69-105.

-106 García-Quiroz J, García-Becerra R, Santos-Martínez N, Avila E, Larrea F, Díaz L: Calcitriol stimulates gene expression of cathelicidin antimicrobial peptide in breast cancer cells with different phenotype. J Biomed Sci 2016;23:78.

107 Barlow PG, Svoboda P, Mackellar A, Nash AA, York IA, Pohl J, Davidson DJ, Donis RO: Antiviral activity and increased host defense against influenza infection elicited by the human cathelicidin LL-37. PLoS One 2011;6:e25333.

108 Bikle DD: Vitamin D and immune function: understanding common pathways. Curr Osteoporos Rep 2009;7:58-63.

109 Gallo RL, Kim KJ, Bernfield M, Kozak CA, Zanetti M, Merluzzi L, Gennaro R: Identification of CRAMP, a cathelin-related antimicrobial peptide expressed in the embryonic and adult mouse. J Biol Chem 1997;272:13088-13093.

110 Zanetti M: The role of cathelicidins in the innate host defenses of mammals. Curr Issues Mol Biol 2005; 7:179-196. 